\title{
Building China's Soft Power for a Peaceful Rise
}

\author{
Li, Xin; Worm, Verner
}

Document Version

Final published version

Publication date:

2009

License

CC BY-NC-ND

Citation for published version (APA):

Li, X., \& Worm, V. (2009). Building China's Soft Power for a Peaceful Rise. Asia Research Centre. Copenhagen Business School. Copenhagen Discussion Papers No. 28

Link to publication in CBS Research Portal

\section{General rights}

Copyright and moral rights for the publications made accessible in the public portal are retained by the authors and/or other copyright owners and it is a condition of accessing publications that users recognise and abide by the legal requirements associated with these rights.

Take down policy

If you believe that this document breaches copyright please contact us (research.lib@cbs.dk) providing details, and we will remove access to the work immediately and investigate your claim. 


\section{$28^{2009 \text { July }}$}

Building China's soft power for a peaceful rise

\section{Xin Li}

Verner Worm 
(C) Copyright is held by the author or authors of each Discussion Paper.

Copenhagen Discussion Papers cannot be republished, reprinted, or reproduced in any format without the permission of the paper's author or authors.

Note: The views expressed in each paper are those of the author or authors of the paper. They do not represent the views of the Asia Research Centre or Copenhagen Business School.

\section{Editor of the Copenhagen Discussion Papers:}

Associate Professor Michael Jacobsen

\section{Asia Research Centre}

Copenhagen Business School

Porcelænshaven 24

DK-2000 Frederiksberg

Denmark

Tel.: (+45) 38153396

Fax: (+45) 38152500

Email: mj.int@cbs.dk

www.cbs.dk/arc 


\title{
Building China's soft power for a peaceful rise
}

\author{
Xin Li \\ Ph.D. Student \\ Asia Research Centre, \\ Copenhagen Business School \\ xl.int@cbs.dk \\ Verner Worm \\ Professor \\ Asia Research Centre, \\ Copenhagen Business School \\ vw.int@cbs.dk
}

\begin{abstract}
With China's rapid economic progress and steady increase in its international influence, China has gradually embarked on the soft power idea and has made developing its soft power as its national strategy. We argue that China's soft power strategy is in accordance to Chinese Confucian culture and political value and fits well with its grand strategy of peaceful rise. Based on existing conceptualizations of soft power, we expanded the sources of soft power to six pillars: cultural attractiveness, political values, development model, international institutions, international image, and economic temptation. We also identified three channels for wielding soft power: formal, economic, and cultural diplomacies. Putting all the basics together, we present an integrative model of soft power. Accordingly, we analyze the sources and limits of China's soft power and suggest how to improve it.
\end{abstract}

Keywords: Soft power, peaceful rise, China, development model, culture. 


\section{China has embarked on the soft power idea}

Over the last three decades since its reform and opening up, China has made a remarkable progress. It has maintained an average close to ten percent annual growth rate in purchase power parity term for thirty years (Worm, 2008). According to the official data of Hong Kong Trade Development Council ${ }^{1}$, China is now the world's third largest economy and the third largest trading nation in the world, the second largest exporter, the largest holder of foreign exchange reserves, and the largest attractor of foreign direct investment (FDI) among developing and transition economies ${ }^{2}$. China's achievement is not confined to economic, but also in other non-economic domains. The United Nations' Human Development Reports reveal that China has made dramatic improvement in terms of Human Development Index, risen continuously from 0.557 in 1980 to 0.777 in 2005 , ranking $81^{\text {st }}$ out of 177 countries $^{3}$. According to a study by the Georgia Institute of Technology, China has rapidly improved its overall technology competitiveness and China may soon rival the United States for world technological leadership ${ }^{4}$. One prominent case is that China has successfully launched its manned spacecraft with three astronauts on board and realized its first-ever space walk in September 2008, which makes China the third country in the world who is able to conduct extravehicular activity in space following the former Soviet Union and the United States ${ }^{5}$. In a backgrounder of the Council on Foreign Relations ${ }^{6}$, Bajoria (2009) argues that China since the 1990s has dramatically improved its military capabilities on land and sea, in the air, and in space, and U.S. military planners see the potential for China to develop as a 'peer competitor'. One evidence could be China's successful anti-satellite missile test in January $2007^{7}$, which shows China has mastered the military capability in space.

On the international stage, China has shown increasing influence. In East Asia, China has hosted the six-party talk on North Korea's nuclear issue. China called for establishing a free trade area with ASEAN (Association of Southeast Asian Nations) which is expected to accomplish in 2010. China and Malaysia proposed the East Asia Summit which will have a significant impact on the geopolitics and power structure of Asia (Nye, 2005). China also hosts the Boao 
Forum for Asia which is sometimes called the Asian version of World Economic Forum in Davos ${ }^{8}$. In Central Asia, China initiated the Shanghai Cooperation Organization and takes part in the six-nation talk on Iran's nuclear issue. In Africa, more and more Chinese engineers and business people appears in many Sub-Saharan countries. In 2006, China successfully held the Beijing Summit of Forum on China-Africa Cooperation which attracted more than 40 African state leaders. In Latin America, China has strengthened its economic cooperative relationships with Mexico, Cuba, Brazil, Argentina, Venezuela, and Chile, among others. In Oceania, China has paid increasing attention to the developing Pacific islands countries which is evidenced by the 2006 ChinaPacific Island summit in Fiji (Wesley-Smith, 2007). In addition, China also strengthens its ties with the US, EU and Australia through the mechanisms of China-U.S. Strategic and Economic Dialogues ${ }^{9}$, China-EU Summit, and free trade area agreement with Australia (and already with New Zealand). On some global issues, China has also made its voices, such as in the WTO Cancun trade talk, in combating Somali pirates, and in dealing with the global financial crisis. China has sent more peace-keeping personnel than three other UN Security Council permanent members - Russia, UK and US (Gill and Huang, 2009). And some Chinese people are starting to assume top positions in international organization, such as the World Health Organization ${ }^{10}$, the World Bank $^{11}$, the International Olympic Committee ${ }^{12}$, and the United Nations ${ }^{13}$. In 2008, China has successfully held the Beijing Olympic Games and China will hold the Shanghai World Expo in 2010.

With this backdrop, Harvard's Professor Joseph S. Nye, the father of soft power theory, saw a clear contrast between the decline of American's soft power (Nye, 2004) and the rise of China's soft power (Nye, 2005). The concept of soft power was first coined in Nye's (1990a) book Bound to Lead: The Changing Nature of American Power. Although the first Chinese article on soft power was published in 1993 by Wang Huning (cited in Li, 2008: 6) ${ }^{14}$, who was then a professor of political science at Fudan University and now a member of the Chinese Communist Party (CCP) Central Committee Secretariat, it is only until recent years that Chinese discourse has paid an enormous amount of 
attention to the idea of soft power and its relevance to China's foreign strategy (Li, 2008). There is a clear surging popularity of the term 'soft power' among Chinese politicians, scholars, journalists and publics ( $\mathrm{Li}, 2008)$. The Chinese government has gradually embarked on a soft power strategy. In his Political Report to the 16th CCP Congress, Jiang Zemin, the former President, points out culture plays an important role in today's global competitition for comprehensive national power (Jiang, 2002). The current Party chief and President $\mathrm{Hu}$ Jintao also made clear that the increase in China's international status and influence will have to be demonstrated in hard power as well as in soft power at the Central Foreign Affairs Leadership Group meeting on 4 January 2006 (cited in Ma, 2007). Hu Jintao further announced that how to improve China's soft power through cultural development is one major practical issue facing the country $(\mathrm{Hu}, 2006)$. In his Political Report to the 17th CCP Congress, Hu once again urges the country to boost its cultural soft power $(\mathrm{Hu}$, 2007).

\section{Why does China need to build soft power}

The reason why China has chosen a soft power strategy is that China has chosen a 'peaceful rise' strategy and China realizes building soft power is an ideal solution for its peaceful rise.

We argue China's rise is inevitable. China is the oldest existing civilization with more than five thousand year history. China used to be the greatest power in the world in its Tang dynasty (AD 618 - 907). For thousands of years, China regarded itself as the superior empire sitting in the centre of the world and the people in distant places as barbarians. In its Ming dynasty (AD 1368-1644), China sent out the world's largest and most advanced fleet seven times to visit and trade with more than 30 countries and territories of the South China Sea and the Indian Ocean between 1405 and 1433, known as 'Zheng He's voyage to the West Sea', half a century before the famous Columbus's voyage to America ${ }^{15}$. Unfortunately, due to the fiscal difficulty caused by the China-centered tribute-trade system and China's blind arrogance, after the 
death of Zheng He, the leader of the great fleet, China suddenly abandoned the sea commerce and re-adopted close-door policy which is believed to have caused the later decline of the imperial China.

Since China's defeat in the Opium War 1840-1842, China, as its people always say, had had 100 years of humiliation before the People's Republic of China was founded. Since the overthrow of the corrupt and weak Manchurian government of Qing Dynasty (AD 1644-1911), Chinese leaders and people have never lost their ambition to restore China as a great power. Unfortunately, for the sake of sovereignty and dignity, China under Mao Zedong successively broke its relationships with the US and the Soviet Union. Anti-capitalism ideology and isolation from the outer world made China left far behind the modernization process of East Asia. At the end of the Cultural Revolution, Chinese economy was at the brink of bankruptcy, Deng Xiaoping decided that China should open up to the outside world and embark on a reform program in 1978. Since then, China has made a phenomenal progress. Many westerners were shocked by Chinese economic miracle. However, we see China's revival inevitable because of China's huge population, vast land, abundant resources, and more important, Chinese people's diligence and steadfast belief, all of which coupled with their determination of opening up can generate unimaginable power.

Power shifts are always dangerous for world peace. However, it can be argued that it is natural for China's rise to be a peaceful one. It is natural because there is no any substantial evidence to predict that China will grow in a non-peaceful route. Chinese history does not support that kind of prediction as well. It is natural also because it is less likely in today's world China will risk to grow through military means because of the increased interdependence between nations which makes military power more costly and less transferable today than in earlier times (Nye, 1990b:159). As Ikenberry (2008) points out that China not only needs continued access to the current global capitalist system but also wants to protect the system's rules and institutions because China has thrived in such system. In the mean time, it is necessary for China to announce its peaceful rise intention in order to reduce the negative impact of the 'China 
threat' argument on its development. Rapid economic growth and military modernization have caused much concern in neighboring countries and in the western world. Some people use the 'China threat' charge and want to contain China's rise. So China now very much needs a peaceful and conducive external environment (Li, 2008: 14) in which China can grow stably during the current 'important period of strategic opportunity' ${ }^{16}$. One way to assure the world its peaceful rise promise is for China to act as a responsible stakeholder in the global system. China has well shown its responsibility during the 1997 Asian financial crisis by not devaluing its currency to help the affected neighboring countries to recover and in current global financial crisis by actively cooperating with other G20 economies and by signing big procurement deals with the EU and the US.

China has also realized that strengthening its soft power is an important and ideal way to realize a peaceful rise. By definition, soft power is different from hard power such as military prowess, and therefore soft power competition is essentially a peaceful race. Soft power theory is also in accordance to Chinese Confucian culture and political value. As Ding (2008:195) comments that the idea of soft power had been consistently advocated and comprehensively utilized by ancient Chinese for more than two millennia. Bell (2008) has interpreted the Confucian views of world order as 'a harmonious political order without state boundaries and governed by a sage by means of virtue, without any coercive power at all' (cited in Ding, 2008: 196). Chinese Communist Party's promotion of a harmonious world ${ }^{17}$ is therefore its reembracing China's traditional culture, and the CCP's desired world order is therefore rather a soft power-based than hard power-based one ${ }^{18}$.

\section{The basics of soft power theory - Toward an integrative model}

China needs not only to reiterate its promise of a peaceful development, but also, more importantly, to rely on effectively building its soft power to improve its attraction and influence. However, currently China still lags behind the US in Asia in terms of soft power (Whitney and Shambaugh, 2008) and Nye 
(2005) sees China's soft power still has a long way to go. Before we can discuss how to improve China's soft power, we need to understand the basics of the theory of soft power pioneered by Professor Joseph Nye.

\subsection{Definition of soft power}

According to Nye (1990b: 154), power means an ability to do things and control others, i.e., to get others to do what they otherwise would not. Nye (2006) further points out three basic means to alter the behaviors of others to get what you want: coercion (sticks), payments (carrots) and attraction (soft power). Nye's classical definition of soft power is the ability to obtain what you want through co-option and attraction rather than the hard power of coercion and payment. While most researches on soft power adopt this definition, some Chinese scholars have broadened the meaning of soft power and applied the concept not only to nations but also regions, organizations and even individuals (cf. Wang and Lu, 2008: 427). Although we see the value of the broader definitions of soft power, such as increasing government's soft power over the people at home, we adopt Nye's original definition here since the focus of the present paper centers on China's international influence.

\subsection{Importance of soft power}

It is widely accepted that soft power is very useful in international relations. We further argue soft power is also useful in economic relations. We identify several ways through which improved soft power can benefit a country's economy. Firstly, it can create a peaceful and conducive environment for economic growth. Secondly, it can boost sales of a country's products in another country by improved national image or by reducing the possibility of boycotting a country's products. Thirdly, it can make a country's cultural products attractive and popular due to its cultural attractiveness. Fourthly, it can help a country to attract more FDI. Fifthly, it can help a country to attract more tourists and business people thus a booming tourism industry. Lastly, it can attract more foreign students to study in the country which generate extra 
income and those students may become a country's 'ambassadors' after returning to their mother countries.

Being a form of power, soft power is directly beneficial for the holder country. Nevertheless, soft power can indirectly benefit other countries. For instance, if a country is to strengthen its soft power by promoting its culture in another country, then the other country will benefit from having an enriched cultural life and more choices of cultural consumption. Since by definition soft power is a power of attraction, attraction to a foreign country's culture, political values and other soft power resources can help another country to understand the attractive country. Therefore, by strengthening soft power of many countries, mutual understanding among nations will be enhanced, hence, peace will be enhanced.

\subsection{Sources of soft power}

In Nye's (2006) conceptualization, there are three (re)sources of soft power: its culture (in places where it is attractive to others), its political values (when it lives up to them at home and abroad), and its foreign policies (when they are seen as legitimate and having moral authority). Most researchers follow this three-source model while some others have tried to broaden the content of soft power. For instance, Chinese scholar Honghua Men (2007) adds another two pillars into Nye's original formula. According to him, in the case of China, soft power has five pillars: cultural attractiveness, political value, economic development model, international institution, and international image. We notice that Nye (2006) has acknowledged 'a success economy is an important source of soft power' which he actually means economic development model (cf. Wuthnow, 2008: 9) and Nye (2007) also sees promoting international image is one important task when it comes to developing China's soft power. Therefore, we accept this broader five-pillar conception of soft power.

In addition to Men's (2007) five pillars, we also identify another neglected source of soft power - a country's economic temptation, namely, if country A offers country B many opportunities for economic gains, then country B would 
be reluctant to provoke country A on non-economic issues. Therefore country $A$ has a soft power over country $B$ in pressuring country $B$ to make policies in favor of or at least not in disfavor of country A. In the case of China, due to the vast Chinese market and business potential, China offers the world enormous opportunities for wealth generation. Few countries would not be lured to such an economic magnet. Therefore, China has a strong soft power in its economic temptation over other countries ${ }^{19}$. China can utilize this soft power resource to alter other countries' policy making to get its desired outcomes.

A clear evidence of this kind of soft power is the fact that the US Secretary of State Clinton played down the human rights issue, which had long been a major issue in the diplomacy between the US and China, when she made her first visit to China after the Obama administration took office in early 2009. Secretary Clinton now talks a 'smart power' strategy, which is a combination of hard and soft power, in dealing foreign affairs because the Obama administration has realized that they cannot succeed in solving the current global financial crisis and other global challenges without cooperation from other countries. Among these countries, China is a key player, which is evident by the emergence of the concept of G2, i.e., the US and China, first proposed by C. Fred Bergsten (2006), the director of the highly-respected think tank Peterson Institute for International Economics in the United States.

We argue these six soft power resources are the major sources of soft power, which can be generalized, i.e., applied to any country. In the meantime, we also argue there might be some country-specific soft power resources which are unique to particular countries while others do not have. For instance, Japanese management system was very influential in the West in 1980s and 1990s. Because Japanese management philosophy and practice was unique and very different from the Western, it gave Japan a unique source of international influence, i.e., Japan's soft power. Another example is ancient Chinese military philosophy, such like Sun Zi's famous writing The Art of War, which is still very influential in the world. 


\subsection{Causal mechanism of soft power}

Huang and Ding (2006: 25) point out that Nye's theory fails to provide 'a causal mechanism to explain how states convert potential soft power resources to realized power or the changed preference/behavior of others'. They have offered such a mechanism which is explained as follows:

'Country A may have various combinations of soft power resources to tap into... These soft power resources can have their impact felt by political elites, interest groups, and the general public ("policy actors") in country B. Assuming the international context favors A's projection of soft power (e.g., lack of viable competition from other countries), country A's reputation, image and influence would be viewed in a positive manner in country $B$, which, in turn, would prompt policy actors in B to be in tune with A's views, approaches, and values in the decision making process. $A$ is said to be able to achieve desired policy outcomes if this policy resonance leads $B$ to directly support A's foreign policy, implement policies that are in A's interests, or look to A for leadership and guidance. Ultimately, the foreign policy success of country A will be translated into extra soft power resources for future use'.

In Huang and Ding's (2006) causal mechanism, we see a feedback loop where country B's policy outcome as a signal is sent back to country A for it to respond accordingly, namely, if the outcome of country B's policy making is in country A's favor, such a foreign policy success of country A will be translated into country A's extra soft power resources for future use; on the other hand, if country B's policy outcome is not in country A's favor, country A will need to improve its soft power resources and strengthen the diplomatic relationship with country B.

In addition to above Huang and Ding's (2006) feedback loop, we also identify another positive feedback mechanism, namely, country B's perception of country A's soft power may be self-reinforced, especially when country B perceives a sudden increase in country A's soft power. For instance, in recent years there is a steady increase of Chinese influence in the US, and with the 
burst of the global financial crisis, there is a sudden increase of China's importance in Americans' eyes. Although China has not changed much over the past few months, the American perception of China's soft power has been strengthened largely due to the positive feedback, i.e., self-reinforcing mechanism. This is clearly shown by an article titled 'Fearing China'20 published on the Newsweek on 20 May 09, which states 'Beijing's flurry of activity is starting to make Americans jittery'.

\subsection{Channels for wielding soft power}

Kurlantzick (2006: 1) argues that soft power can be 'high', targeted at political elites, or 'low', targeted at the broader public. These two parts of soft power are different for two reasons. One is that high soft power is more direct than low soft power because political elites can exert more immediate impact on policy making than general public can. Normally, general public can impact policy making through public opinion, protest, and referendum. Another reason is the fact that soft power over high level political elites does not directly translate into soft power over low level general public, an evidence being the contrast that while the White House sends goodwill gestures to China the US congress expresses hostility (Wang, 2008:260).

In connection with Huang and Ding (2006), we add a middle level of soft power, targeted at the interest groups whose impact on a country's policy-making is more direct than the low level general public but less direct than the high level political elites. Interest groups include business associations, ethnic groups, trade unions, non-governmental organizations, and others. We argue there are accordingly three basic channels through which a country can wield its soft power to influence another country: formal diplomacy targeting the political elites, economic and public diplomacy targeting interest groups, and public diplomacy targeting the general public of another country.

\subsection{An integrative model of soft power}


To put all the basics abovementioned together, we present an integrative model of soft power in Figure one.

Figure one - An integrative model of soft power

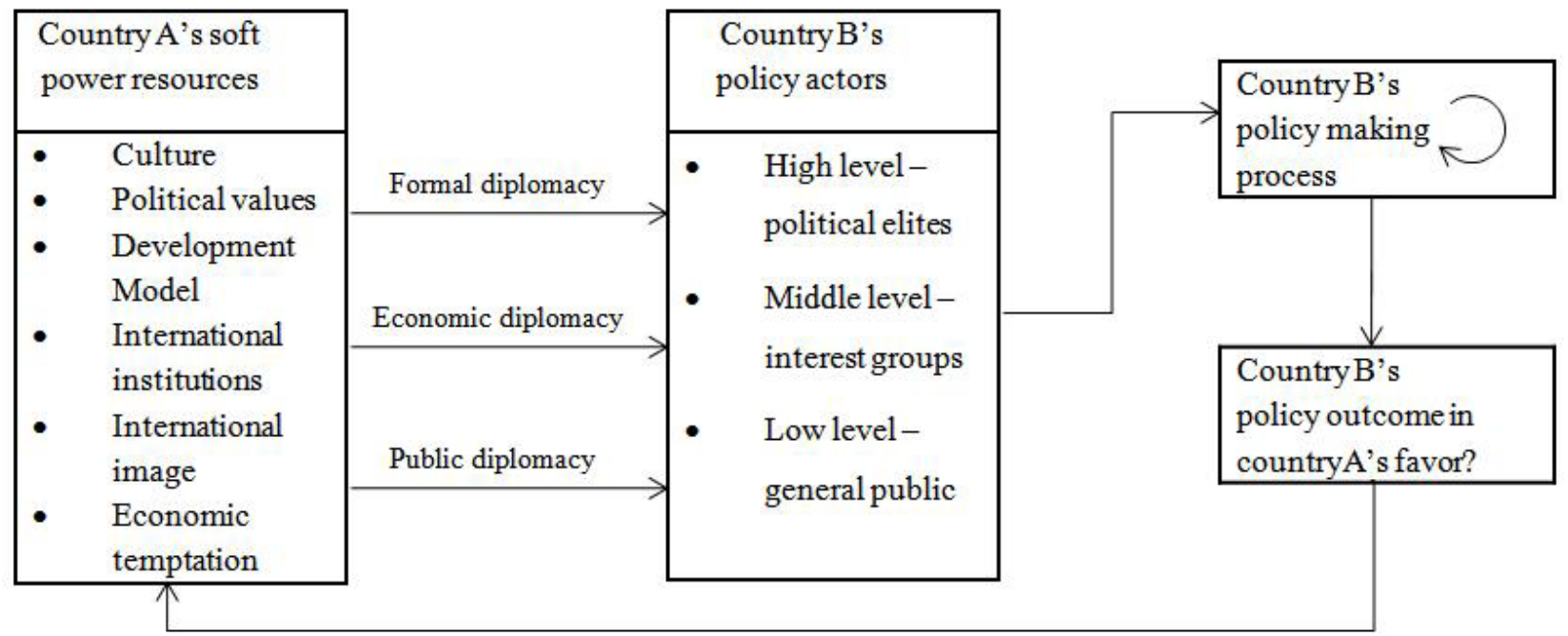

\section{How to build China's soft power}

Accordingly, China can build its soft power in six areas and wield through three diplomatic channels.

\subsection{Culture}

In terms of cultural attractiveness, China has enormous competitive cultural resources. According to an international survey in 1999, China was regarded as a nation with a unique culture and tradition (Lai, 2006). Nurtured by its five thousand year history, China now owns many unique and attractive cultural resources, e.g., Chinese language (characters and calligraphy), Chinese philosophy (Confucianism, Zhong-Yong, Yin-Yang, and art of war), Chinese Buddhism, Chinese music (Chinese traditional music is performed in Vienna Golden Hall since 1997), movies (especially martial art movies), arts (porcelain, painting, handicrafts, etc.), architecture, Chinese food, Chinese medicine, Chinese Kongfu (martial arts and Tai Ji), Chinese Spring Festival, and China towns in major cities all over the world. 
In recent years China has paid much more attention on promoting Chinese culture overseas. For instance, Until October 2008, China has established 326 Confucius Institute in 81 countries and regions ${ }^{21}$ to promote Chinese language and culture, and China plans to have 500 Confucius institutes worldwide by $2010^{22}$. In addition, China undertakes over 1300 cultural exchanges a year, such as sponsoring 'Year of Chinese culture', 'Chinese cultural festival' and Chinese New Year celebrations in the US, France, the UK, Russia, and Thailand (Lai, 2006: 2). China also hosted the first World Chinese Conference ${ }^{23}$ in July 2005 and the first international Buddhism forum in 2006. China now sends more and more movies to the international movie festivals.

However, in spite of such rich resources and great efforts, China still lags far behind the US in terms of cultural influence overseas because China lacked of an overall strategy for culture and Chinese cultural industry is small and lacks of international competitiveness partly because it is difficult to export. Chinese government has realized this limitation and made its first ever five-year plan for cultural development ${ }^{24}$ in 2006 which stipulates the reform of its cultural management system and the development of its cultural industries. We see this plan very timely and valuable. We suggest Chinese government should further consolidate the coordination of cultural resources overseas because many of the cultural promotion activities are still performed on an ad hoc basis which limits their influence. If most of these ad hoc activities are to be coordinated, synergy effect will help generate much more influence. We think the Confucius Institute can be such a coordinating agency. This then demands more financial and human resources that are problematic currently, due to a mismatch between the rapid expansion of the number of Confucius Institutes and the necessary organizational capability which can only build over time.

\subsection{Political values}

There are two aspects of a country's political values: one domestic, i.e., how the government rules its own people, and one international, i.e., the principles and policies when dealing with other nations and international affairs. 
Western scholars frequently criticize Chinese domestic political values by referring to lack of democracy, violating human rights and suppression of freedom, and some scholars argue this is the underbelly of China's soft power (Huang and Ding, 2006: 32; Lai, 2006: 12). Admittedly, there are many problems in China: corruption, censorship, unequal opportunities, privileged class, and lack of transparence, etc. After all, many people believe China is still an authoritarian regime (e.g., Nathan, 2003). We support Colley's (2009) viewpoint that many people (especially in the West) tend to see China's development as a glass half empty or largely focus on the negative aspects of China's development. What those people neglected is the fact that Chinese government has made much progress in terms of political civilization ( $\mathrm{Yu}, 2007)$ since the start of reform and opening up while its process is a rather incremental one (Yu, 2008). Started since the end of Cultural Revolution before which the main political ideology was class struggle, Chinese Communist Party has been drastically reforming its political system and improving its domestic political values. Many new ideas have been officially adopted by the CCP government, such as hearing system in 1996, rule of law in 1997, civil society in 1998, developing political civilization in 2001, human-oriented in 2003, protection of human rights and protection of private property written in national Constitution in 2004, and building a socialist harmonious society in 2004. Colley (2009) argues 'when Chinese leaders like Wen Jiabao talk of "putting people first" and developing a "harmonious society", they tend to mean it'. We argue China needs and can have more and substantial improvement in domestic governance because even within the current political system a one party democracy can be developed; and in the mean time, China needs to better communicate with outside world what progress China has made and what the political reform it plans to proceed.

Internationally, China has consistently followed the principles of peaceful coexistence and no-interference of other nation's domestic affairs which reward China a friendly and peaceful image in many countries. China's proposal of building a harmonious world not only is consistent with its long-held peaceful coexistence principle but also offers the world a brighter new world order. 
According to Wang and Lu (2008), in the reform ear, Chinese has adopted an independent foreign policy, i.e., resistant to outside pressure, free from alignment, non-ideological, and non-confrontational, which together with its good neighbor policy have made China appealing. China has been sensitive to being seen as a responsible stakeholder and behaving accordingly. For instance, in 1997 Asian financial crisis, Chinese government resisted the pressure for RMB devaluation which helped East Asia recover at China's own expense of detrimental economic consequences in short run. In dealing with North Korean nuclear crisis, China abandoned the ideological approach it had used in Maoist time and played an active mediating role in the six-party talk. In order to promote peace, China has also made unprecedented concessions in solving the territorial disputes with its neighboring countries (Fravel, 2005). We see these as a strong source of China's soft power.

Although some scholars argue China's practice of non-interference might jeopardize some western countries' efforts to pressure some dictatorship regimes to democratize their domestic governances, we argue China should not compromise on this non-interference principle. The normal practices of Western powers is to use economic sanction and arms embargo to force changes in domestic governance, which can be argued to have little and even negative impact on solving the very problems. Simply, many sanctioned countries are those in urgent need of economic development and economic sanction may bring human disasters to those countries. Having said this, we nevertheless suggest China to be more flexible to work more closely with international organizations and relevant western powers to find alternative ways to solve those problems.

\subsection{Development model}

So far, China's economic growth has been impressive and successful, which gives China another very strong source of soft power (cf. Wang and Lu, 2008: 429). This is evident when countries, authoritarian or liberal, like North Korea, Vietnam, Laos, Russia, Kazakhstan, Uzbekistan, Turkmenistan, India, 
Iran, Brazil, and Zimbabwe have shown their interest in the so-called 'Beijing Consensus' (Huang and Ding, 2006:29), coined by Joshua C. Ramo in 2004, as an alternative development model to the withering Washington Consensus.

However, some scholars, from China and abroad, argue against the Chinese economic development model as it has some serious problems, such as corruption, pollution, environment degradation, high consumption with low efficiency of use of energy and resources, rural-urban gap, regional disparity and income disparity, etc. Admittedly, these are serious challenges facing China, but they are problems of the development process. No country can grow without problems. It is not easy to have made such a progress in a short period for a big country like China with a 1.3bn population and starting from a very poor basis. Moreover, Chinese leaders have been aware of these problems and have decided to switch to a better development strategy - the so-called 'scientific development view' - which aims to build a more sustainable and harmonious society. According to this new development strategy, China aims to reduce the gaps between urban and rural areas, between rich and poor, between coastal east and inland west; China is to transform the central and local governments into clean and efficient service-type governments; and China strives to upgrade its economic structure by strengthening high-value-added industries and making obsolete those of high energy consumption, high pollution and low-efficiency. So, it is critical for China to make these changes happen. The success of China's economic development will not only benefit Chinese people but also contribute to the development economic thinking globally.

In addition to its domestic success, Chinese development model has another dimension of attraction: it offers the developing country 'opportunities not available under established structures of power' (Wesley-Smith, 2007). In the 1990s, many developing countries had to implement Washington Consensus-based reform agenda because there was no alternative while the international pressures were too great to do otherwise, and the capacity of international financial institutions to compel obedience too large' (cited in Wesley-Smith, 2007: 21). And often times, western aid donors attach stringent conditionality when giving developing countries international aid. The 
conspicuous lack of success of such Washington Consensus-based reform efforts in the 1990s (World Bank, 2005) has given the Chinese model of independent development and no-strings-attached aid a warm welcome in the Global South. In Chinese Premier Wen Jiabao's (2006) words, China can offer the developing world 'a new model for South-South cooperation' which is based on 'peaceful coexistence, equality, and respect for the social systems, sovereignty, and independence of [other nations]' and China's willingness 'to provide assistance without any political strings attached' (Wesley-Smith, 2007: 23).

As Wang and Lu (2008: 440) point out Chinese government has shunned the more provocative phrase of 'Beijing Consensus' but Chinese officials have not been shy to speak of the Chinese development model. This is partly because China does not want to raise a different banner that competes with the Washington Consensus (Yu, 2004) while Chinese officials see the Socialism with Chinese characteristics as a viable alternative to the Western theory of modernization. Apparently, China has learned the lessons of its zealous effort to export its revolutionary model during Mao's leadership, so Chinese government is quite prudent in promotion its development model nowadays. Nevertheless, we suggest China to find a flexible way to communicate its development model to strengthen its soft power because 'the demonstration effect of the Chinese model as part of China's political and moral power' (Wang and Lu, 2008: 440).

\subsection{International institutions}

Wang and Lu (2008: 425) point out a country's ability to frame the international agenda and set the rules of the game is an important type of soft power.

China's attitude towards participating international institutions has changed noticeably from little interested in the early opening era to proactive in recent years. In the mid-1960s, China was virtually isolated from international organizations when the government of Republic of China in Taiwan was representing China in the United Nations. Huang and Ding (2006: 30) observe 
there has been a dramatic increase of China's participation in international institutions and organizations in the post-Mao era. According to the Union of International Association's 1994/1995 Yearbook of International Organization, China's membership numbers exceeded 1000. Huang and Ding (2006: 30) also reveal China's compliance with international normative regimes is mixed and varies from poor to fair (in human rights) to fair (nonproliferation and national self-determination) and to good or excellent (free trade and sovereignty).

China is one of the five permanent members of the UN Security Council with veto power, which gives China a very strong position in international security. However, China's influence on global financial and trade systems is very limited. China has been members of the World Bank and the International Monetary Fund (IMF) yet with little voting rights. China joined the World Trade Organization in 2001 after substantial compromises but China does not obtained the status of market economy.

The 2008 global financial crisis gives China a unique opportunity to gain more influence in reorganizing the international financial order. With a strong growing economy and the world largest foreign exchange reserve before the outbreak of the global financial crisis, China has been seen by many people as a savior who is able to rescue the world. American think tank Peterson Institute for International Economics coined the G2 notion which was later supported by the World Bank's president and chief economist (Zoellick and Lin, 2009). We suggest China to closely cooperate with other developing countries as well as developed countries of the G20, in so doing, China will become more active and gain more influence in global financial system. In the mean time, China should make substantial improvements in those areas with poorer compliance scores such as human rights.

\subsection{International image}

A country's international image is shaped by the behaviors and performances of its government, multinational corporations, products and brand names, and people. The Hu Jintao-Wen Jiabao administration embraces the 
idea of 'putting people first' and 'building harmonious society' since they took office, which has helped improve its governmental image home and abroad, for instance, from the quick response to the SARS epidemic to the rescue action in the Sichuan earthquake, from the success hosting the Beijing Olympic Games to granting foreign journalists rights to free interview in China. But as China still being viewed an authoritarian government (Nathan, 2003), westerners will always have some negative image about it.

Encouraged by the 'go out' strategy, there are more and more Chinese big corporations investing overseas. How these companies behave abroad will have a direct impact on China's international image. And negative press can cause much damage on a country's international image. For instance, some scholars observe some irresponsible conducts of Chinese companies in and the negative impacts on African countries which have created much tension between Chinese multinationals and the people of investing countries. Some people even charge Chinese businesses in Africa conducting neo-colonialism. Although it can be argued that Chinese investment in developing countries, especially in Africa, has brought more benefit than damage to those countries, China is still low on the learning curve with regard to outward foreign direct investments.

Chinese-made products are now sold all over the world. Normally, Chinese products are seen as cheap and lower quality than products from OECD countries. The cheap Chinese goods benefits many rich countries by keeping the inflation rate low and helping consumers cut living expenses. But the quality problems can have a very negative impact on China's international image, such as the toxic milk scandal in 2008. Of course, there are more and more high quality products made in China, such as Lenovo computers, Haier refrigerators, Galanz microwave ovens and TCL TV-sets, among others. So, it is important that China builds its own industrial base consisting of multinational companies that are competitive internationally.

Overseas Chinese, visiting scholars and students studying abroad can also shape China's international image. Normally, Chinese people abroad are 
seen as polite and modest. Recent years, the number of Chinese students studying overseas has increased dramatically. More and more young Chinese students (under 18 years old) are sent abroad. As many of them are over-loved at home, some youngsters might not hold many traditional Confucian values, such as respecting elderly people, being modest, and hardworking and discipline, it is likely that they will behave different from those mature Chinese fellows, which may give local people of host countries a very different image about Chinese from their normally-held impressions.

To improve China's international image and remove the misunderstanding of China, Chinese government has decided to invest USD 6.6bn (CNY 45bn) to expand the reach and impact of its state-run media (Lawrence, 2009), such as the China Central Television (CCTV), Xinhua News Agency, and China Daily. Nevertheless, Chinese government has to learn how to improve its international image through public relations. For instance, in 2009 Chinese navy intended to send the world a clear message of its willingness to build a 'harmonious ocean' 25 by sending its anti-pirate fleet to the Gulf of Aden and holding its first national naval parade. However, an article published by Singapore's Straits Times on 15 May 2009 pointed out that Chinese navy needs public relations representatives who are adept at dealing with media and communication $^{26}$. In addition to governmental efforts, Chinese companies should strictly adopt corporate social responsibility principle to self-regulate their business conducts overseas, and Chinese people should behave nicely abroad. Especially, Chinese companies should pay close attention to product quality and food safety, and Chinese people should try their best to correct those apparent misunderstanding about China when communicating with foreigners.

\subsection{Economic temptation}

China should make efforts to maintain and increase its economic temptation to the world. In recent years, due to the increase of wage level, appreciation of Chinese currency, changes in Chinese labor law and environmental regulations, China is losing its cost competitiveness to lower- 
wage countries like Vietnam and India. Many foreign investors have relocated their investments from China to other places. This is a serious challenge to China.

To keep foreign investments and attract more FDI is very important to the Chinese economy. We suggest China to take two solutions to tackle this problem. One is for China to offer more business and investment opportunities to foreigners in its inland Midwest where the wage level is much lower than coastal region. China needs to give foreign investors many incentives, such as beneficial tax rates and good infrastructures while not compromising on the labor law and environmental regulation. We are sure about the business and investment potential of China's Midwest. In 1999, Chinese government proposed the strategy of developing China's west. Although there have been much progress in west regions, the gap between the east and the west has been widening (Han, Zhang, and Ma, 2008). Attracting FDI to China's vast Midwest seems to be an ideal solution to boost development at the moment.

Second solution is for China to quickly upgrade its industrial structure to attract more high-value-adding businesses to invest in China. This is not only important for China to attract more foreign investment to fill the void left by relocation of some foreign businesses to other places, but also crucial for China to make its economy more competitive and sustainable. Since its opening up, China has attracted much of the world's low-value-adding manufacturing investment to its coastal east, while these labor-intensive FDIs help providing employment opportunities for China's migrant workers and generating export revenues, they also have caused many problems such as large consumption of natural resources, environmental pollutions, and imbalances in Chinese economy, i.e., too export-led growth pattern. Since China has rich human resources and sufficient financial capacity, we argue, if China can dedicate its resources into this industrial upgrade, we believe China can not only grow steadily but also offer the world more business and investment opportunities, hence more economic temptation. 
China needs to use more economic diplomacy to promote its business and investment opportunities overseas. China should send more delegations abroad to run investment promotion roadshow, hold more conferences on business and investment in China, and use international forums such as World Economic Forum annual conference to introduce investment opportunities in China.

\section{Reference}

Bajoria, J. 2009. 'Backgrounder: China's military power', Council on Foreign Relations, February 4, available at: http://www.cfr.org/publication/18459/ [accessed on 8 May 2009]

Bell, D. A. 2008. 'Just war and Confucianism: Implications for the contemporary world', in D. A. Bell (ed.) Confucian Political Ethics, Princeton, NJ: Princeton University Press, p. 227

Bergsten, C. F. 2006. 'Clash of the Titans', Newsweek, International Edition, April 24

Colley, C. 2009. 'China's reforms at 30 and the "Beijing Consensus"', Pambazuka News, China-Africa Watch section, January 31, Issue 417, available at: http://pambazuka.org/en/category/africa_china/53757 [accessed on 8 May 2009]

Ding, S. 2008. 'To build a "harmonious world": China's soft power wielding in the global south', Journal of Chinese Political Science, 13(2): 193-213

Fravel, M. T. 2005. 'Regime insecurity and international cooperation: Explaining China's compromises in territorial disputes', International Security, Vol. 30, No. 2, pp. 46-83

Gill, B. and Huang, C. 2009. 'China spreads its peacekeepers', Asia Times, February 4, available at: http://www.atimes.com/atimes/China/KB04Ad01.html [accessed on 9 May 2009] 
Han, J., Zhang, R., and Ma, Z. 2008. 'Analysis on Reasons of Widening Development Gap between the Easter Region and the Western Region in China', Science, Economy, Society, 26(1): 11-15, (in Chinese) available at: http://ilib.com.cn/A-kxjjsh200801003.html [accessed on 25 May 2009]

Hu Jintao 2006. Speech on the Eighth National Congress of the China Federation of Literary and Art Circles, November 10, available at: http://culture.people.com.cn/GB/22219/5026372.html [accessed on 10 May 2009]

Hu Jintao 2007. Political Report to the $17^{\text {th }}$ CCP Congress, October 15, available at: http://news.xinhuanet.com/newscenter/200710/24/content_6938568.htm [accessed on 10 May 2009]

Huang, Y. and Ding, S. 2006. 'Dragon's underbelly: An analysis of China's soft power', East Asia, 23(4): 22-44

Ikenberry, G. J. 2008. 'The rise of China and the future of the West: Can the liberal system survive?', Foreign Affairs, January/February

Jiang Zemin 2002. Political Report to the $16^{\text {th }}$ CCP Congress, 8 November, available at: http://news.xinhuanet.com/ziliao/200211/17/content_693542.htm [accessed on 26 May 2009]

Kurlantzick , J. 2006. 'China's charm: Implication of Chinese soft power', Policy Brief No. 47, June, Carnegie Endowment for International Peace, available at:

http://www.carnegieendowment.org/publications/index.cfm?fa=view\&id=184 01 [accessed on 18 May 2009]

Lai, H. 2006. 'China's cultural diplomacy: going for soft power', EAI Background Brief No. 308, East Asian Institute, National University of Singapore, Singapore

Lawrence, D. 2009. 'China's "soft-power" strategy threatened by Obama, slow growth', available at: http://www.bloomberg.com/apps/news?pid=20601080\&sid=aS0aumUfVlyM \&refer=asia [accessed on 19 May 2009] 
Li, M. 2008. 'Soft power in Chinese discourse: Popularity and prospect', Working Paper No. 165, S. Rajaratnam School of International Studies, Nanyan Technological University, Singapore

Ma, L. 2007. 'Guanyu wo guo jiaqiang ruan shili jianshe de chubu sikao' [A Primary Thought on China Enhancing the Construction of the Soft Strength],Dang De Wenxian [Literature of Chinese Communist Party], No 5. (in Chinese)

Meng, H. 2007. 'Zhongguo ruan shili pinggu baogao [Assessment report on China's soft power]', Guoji Guancha [International Watch], 2: 15-26 (in Chinese)

Nathan, A. 2003. 'Authoritarian Resilience', Journal of Democracy, 14(1): 6-17 Nye, J. 1990a. Bound to Lead: The Changing Nature of American Power. New York: Basic Books

Nye, J. S. Jr. 1990b. 'Soft Power', Foreign Policy, 80: 153-171

Nye, J. S. 2004. 'The decline of America's soft power', Foreign Affairs, May/June

Nye, J. S. 2005. 'The Rise of China's Soft Power', Wall Street Journal Asia, December 29

Nye, J. S. 2006. 'Think again: Soft power', Foreign Policy, 1 March. Available at: http://yaleglobal.yale.edu/display. article?id=7059 [accessed on 11 May 2009]

Nye, J. S. 2007. 'The Rise of China's Soft Power', Speech at Peking University, Beijing, December 18, available at:

http://ennews.pku.edu.cn/news.php?s=197954479 [accessed on 26 May 2009]

Ramo, J. C. 2004. The Beijing Consensus. London: The Foreign Policy Centre Union of International Association 1994. Yearbook of International Organization, Vol. 2, 1994/1995, New Providence: K. G. Saur 
Wang, H. and Lu, Y. 2008. 'The conception of soft power and its policy implications: a comparative study of China and Taiwan', Journal of contemporary China, 17(56): 425-447

Wang, Y. 2008. 'Public diplomacy and the rise of Chinese soft power', ANNALS, AAPSS, 616, March: 257-273

Wen Jiabao 2006 'Win-win cooperation for common development', Keynote speech, China-Pacific Island Countries Economic Development and Cooperation Forum, Nadi, Fiji, April 5, available at: http://news.xinhuanet.com/english/2006-04/05/content_4385969.htm [accessed on 11 May 2009]

Wesley-Smith, T. 2007. China in Oceania: New forces in Pacific politics. Honolulu, Hawaii: East-West Center

Whitney, C. B. and Shambaugh, D. 2008. Soft power in Asia: Results of a 2008 multinational survey of public opinion. Chicago: The Chicago Council on Global Affairs, Available at: http://www.thechicagocouncil.org/UserFiles/File/POS_Topline\%20Reports/ Asia\%20Soft\%20Power\%202008/Soft\%20Power\%202008_full\%20report.p df [accessed on 11 May 2009]

World Bank 2005. Economic Growth in the 1990s: Learning from a Decade of Reform. Washington D. C.: The World Bank

Worm, V. 2008. 'Introduction', in V. Worm (ed.) China-Business Opportunities in a Globalizing Economy. Copenhagen: Copenhagen Business School Press

Wuthnow, J. 2008. 'The concept of soft power in China's strategic discourse', Issues \& Studies, 44(2): 1-28

Yu, K. 2004. 'A dialogue about the "Beijing Consensus" and the Chinese development model' ['Guanyu "Beijing Gongshi” yu Zhongguo Fazhan Moshi de Duihua'], Dangdai Shijie yu Shehui Zhuyi, No. 5, pp. 4-9

Yu, K. 2007. 'Yu Keping on the development of China's socialist democracy', available at: http://web.xwwb.com/wbnews.php?db=11\&thisid=108122 [accessed on 12 May 2009] 
Yu, K. 2008. 'Democracy and political progress in China', available at: http://www.china.org.cn/english/congress/229019.htm [accessed on 12 May 2009]

Zoellick, R. B. and Lin, J. Y. 2009. 'Recovery rides on the "G-2"', The Washington Post, March 6, available at:

http://www.washingtonpost.com/wp-

dyn/content/article/2009/03/05/AR2009030502887_pf.html [accessed on 19 May 2009]

\section{Notes}

\footnotetext{
${ }^{1}$ http://www.hktdc.com/info/mi/a/mp/en/1X000JPQ/1/Market-Profiles/Market-Profile-on-ChineseMainland.htm

2 Data source: United Nations Conference on trade and Development's (UNCTD) World Investment Report 2008, on page 1of the Overview, available at: http://www.unctad.org/en/docs/wir2008intro_en.pdf

${ }^{3}$ http://hdrstats.undp.org/countries/country_fact_sheets/cty_fs_CHN.html

${ }^{4}$ http://www.semiconductor.net/article/CA6525322.html

${ }^{5}$ http://news.xinhuanet.com/english/2008-09/25/content_10111476.htm

${ }^{6}$ http://www.cfr.org/publication/18459/

${ }^{7}$ http://www.washingtonpost.com/wp-dyn/content/article/2007/01/18/AR2007011801029.html

${ }^{8}$ http://www2.chinadaily.com.cn/cndy/2008-04/16/content_6619837.htm

${ }^{9}$ http://news.xinhuanet.com/english/2009-05/07/content_11325868.htm

${ }^{10} \mathrm{http}: / /$ www.who.int/dg/chan/en/index.html

$11 \mathrm{http}: / /$ www.chinastakes.com/article.aspx?id=162

12 http://www.olympic.org/uk/games/beijing/full_story_uk.asp?id=2696

13 http://www.un.org/esa/desa/ousg/biography.html

${ }^{14}$ Wang Huning 1993. 'Zuowei guojia shili de wenhua: Ruan quanli' [Culture as national power:

Soft power], Fudan Journal (Social Sciences edition), Issue 3, available at:

http://www.lunwentianxia.com/qikan_detail_qis/479010/

15 http://www.chinavoc.com/history/ming/zh.htm

${ }^{16}$ In his Political Report to the 16th CCP Congress, Jiang Zemin points out that the first 20 years of the $21^{\text {st }}$ century is an important period of strategic opportunity for China.

${ }^{17} \mathrm{Hu}$ Jintao first annouced the idea of building a harmonious world in his speech to the UN Summit on 16 September 2005. The speech is available at: http://www.fmprc.gov.cn/ce/ceun/eng/zt/shnh60/t212614.htm
} 
${ }^{18}$ This is not to deny the protective role of a military force which Nye (1990b: 160) also regards relevant.

${ }^{19}$ This is clearly reflected in Huang and Ding (2006: 38-39).

${ }^{20} \mathrm{http}: / /$ www.newsweek.com/id/198586

${ }^{21}$ http://english.hanban.edu.cn/content.php?id=3622

${ }^{22}$ http://www.china.org.cn/english/education/200268.htm

${ }^{23}$ http://www.china.com.cn/market/shihanE/412920.htm

${ }^{24}$ http://culture.people.com.cn/GB/22226/71018/index.html

${ }^{25}$ http://english.peopledaily.com.cn/90001/90776/90786/6636723.html

${ }^{26}$ http://www.chinanews.com.cn/gn/news/2009/05-22/1703415.shtml 


\section{COPENHAGEN DISCUSSION PAPERS}

2005:

2005-1 May: Can-Seng Ooi - Orientalists Imaginations and Touristification of Museums: Experiences from Singapore

2005-2 June: Verner Worm, Xiaojun Xu, and Jai B. P. Sinha - Moderating Effects of Culture in Transfer of Knowledge: A Case of Danish Multinationals and their Subsidiaries in P. R. China and India

2005-3 June: Peter Wad - Global Challenges and Local Responses: Trade Unions in the Korean and Malaysian Auto Industries

2005-4 November: Lenore Lyons - Making Citizen Babies for Papa: Feminist Responses to Reproductive Policy in Singapore

2006:

2006-5 April: Juliette Koning - On Being "Chinese Overseas": the Case of Chinese Indonesian Entrepreneurs

2006-6 April: Mads Holst Jensen - Serve the People! Corporate Social Responsibility (CSR) in China

2006-7 April: Edmund Terence Gomez - Malaysian Investments in China: Transnationalism and the 'Chineseness' of Enterprise Development

2006-8 April: Kate Hannan - China's Trade Relations with the US and the EU WTO Membership, Free Markets (?), Agricultural Subsidies and Clothing, Textile and Footwear Quotas

2006-9 May: Can- Seng Ooi - Tales From Two Countries: The Place Branding of Denmark and Singapore

2006-10 May: Gordon C. K. Cheung - Identity: In Searching the Meaning of Chineseness in Greater China

2006-11 May: Heidi Dahles - 'Chineseness' as a Competitive Disadvantage, Singapore Chinese business strategies after failing in China

2006-12 June: Émile Kok- Kheng Yeoh - Development Policy, Demographic Diversity and Interregional Disparities in China 
2006-13 June: Johannes Dragsbaek Schmidt - China's "soft power" reemergence in Southeast Asia

2006-14 September: Michael Jacobsen - Beyond Chinese Capitalism: ReConceptualising Notions of Chinese-ness in a Southeast Asian Business cum Societal Context

2006-15 October: Ng Beoy Kui - The Economic Rise of China: Its Threats and Opportunities from the Perspective of Southeast Asia

2007:

2007-16 February: Michael Jacobsen - Navigating between Disaggregating Nation States and Entrenching Processes of Globalisation: Reconceptualising the Chinese Diaspora in Southeast Asia

2007-17 April: Émile Kok-Kheng Yeoh, Shuat-Mei Ooi - China-ASEAN Free Trade Area: Implications for Sino-Malaysian Economic Relations

2007-18 May: John Ravenhill, Yang Jiang - China's Move to Preferential Trading: An Extension of Chinese Network Power?

2007-19 May: Peter J. Peverelli - Port of Rotterdam in Chinese Eyes

2007-20 June: Chengxin Pan - What is Chinese about Chinese Business? Implications for U.S. Responses to China's Rise

2007-21 September: Charles S. Costello III - The Irony of the Crane: Labour Issues in the Construction Industry in the New China

2007-22 October: Evelyn Devadason - Malaysia-China Network Trade: A Note on Product Upgrading

2007-23 October: LooSee Beh - Administrative Reform: Issues of Ethics and Governance in Malaysia and China

2007-24 November: Zhao Hong - China- U.S. Oil Rivalry in Africa

2008:

2008-25 January: Émile Kok-Kheng Yeoh - Ethnoregional Disparities, Fiscal Decentralization and Political Transition: The case of China 
2008-26 February: Ng Beoy Kui - The Economic Emergence of China: Strategic Policy Implications for Southeast Asia

2008-27 September: Verner Worm - Chinese Personality: Center in a Network

2009:

2009-28 July: Xin Li, Verner Worm - Building China's soft power for a peaceful rise

2009-29 July: Xin Li, Kjeld Erik Brødsgaard, Michael Jacobsen - Redefining Beijing Consensus: Ten general principles 